\title{
GAY ISSUES AND THEMES IN PHILIPPINE INDEPENDENT AND MAINSTREAM FILMS
}

\author{
${ }^{*}$ Orville B. Tatcho ${ }^{1}$ and Ariel S. Barrias ${ }^{2}$ \\ ${ }^{1}$ University of the Philippines Baguio \\ ${ }^{2}$ Philippine Science High School - Ilocos Region Campus
}

\begin{abstract}
While a lot of film studies look at how gay characters are portrayed or depicted in films, this study aims to identify various gay issues presented in select Philippine gay-themed films. Using critical discourse analysis, the two-fold objective in this paper is addressed by surfacing various gay issues presented in a mix of independent (indie) and mainstream films produced in the Philippines from 1998 to 2013. Gay issues in these films include themes on representation, acceptance, and rights and protection. After uncovering the issues and themes in these gay-themed films, the paper explicates the nuances of indie and mainstream films which could affect the selection of gay issues to be presented, how the issues are presented, and which audience or sectors are catered to. These nuances include differences in modes of production, use of technology, and production techniques. Overall, the political economy of media informs the study on the missing discourses about gay representation, identity and agency.
\end{abstract}

Keywords: gay issues, indie, mainstream

\section{INTRODUCTION}

In spite of their greater visibility and positive contributions, gays have not always been cast in a positive light in Philippine cinema. Their portrayal and representation breed and support gay stereotypes. In the past, there were very few Filipino movies which dealt with the subject of homosexuality. Gay characters are caught up in formulaic narratives in mainstream films which are produced by the major studio system for the mass market. Today, the rise of independent films exploring the topic of homosexuality has opened discussions on whether indie films provide an alternative perspective to mainstream films about the topics of gay identity, issues, and experience.

This study aims to critically analyse how gay issues are presented in Philippine cinema or to be more specific, in select indie and mainstream films. The two-fold objective of this paper are a) to uncover gay issues and themes in the films and b) to explicate the nuances of indie and mainstream films which affect the presentation of gay issues and themes. A simple distinction between indie and mainstream films that could be made at this point relates to the economic mode of production-indie films are produced outside the major studio system which sustain mainstream films. Another important phrase that needs definition is "gay issue". What exactly constitutes a "gay issue"?

Gay issues in films refer to "struggles (of homosexuals) that address their otherness or their being different" (p. 157). According to Jamon (2006):

$$
\begin{aligned}
& \text { "Gay films place the homosexual } \\
& \text { character at the center of the } \\
& \text { narrative. Often these films present } \\
& \text { homosexual issues and struggles that } \\
& \text { address their "otherness" or their } \\
& \text { being different. Common conflicts in } \\
& \text { gay films involve the lack of } \\
& \text { recognition and acceptance from the } \\
& \text { society they are in, or the dilemma of } \\
& \text { whether or not to come out and } \\
& \text { accept one's homosexuality." ( } p .157)
\end{aligned}
$$

As such, the gay issues uncovered in this study can be understood in the context of similar themes of otherness, acceptance, and struggle. 


\section{About the movies}

The films in this study are a mix of independent and mainstream films and were chosen on account of the gay characters, narratives, and issues they tackle, directly or indirectly. The films reviewed in this paper are Pusong Mamon (Soft Hearts), Sa Paraiso ni Efren (Efren's Paradise), Ang Pagdadalaga ni Maximo Oliveros (Blossoming of Maximo Oliveros), Ang Lihim ni Antonio (Antonio's Secret), Girl Boy Bakla Tomboy (Girl Boy Gay Lesbian), and Bekikang.

Pusong Mamon (Soft Hearts, 1998) is a comedy set in Manila about a woman's entanglement in a gay couple's relationship. Directed by Joel Lamangan, Annie (Lorna Tolentino), Ron (Albert Martinez), and Nick (Eric Quizon) star in this film (Caw, n.d.).

Sa Paraiso ni Efren (Efren's Paradise, 1999) is about Melvin, a social worker who frequents a night club where he met Efren, one of the dancers. Melvin is attracted to Efren and moves in with him, only to find out that Efren already has sexual relationships with three other women (Deming, n.d.).

Ang Pagdadalaga ni Maximo Oliveros (The Blossoming of Maximo Oliveros, 2005) has an effeminate boy named Maxi (Nathan Lopez) for its lead character. Maxi enacts the roles of a mother, sister, and friend to his family of petty crooks and "promptly tumbles head over heels in puppy love" upon meeting a handsome police officer, Victor played by JR Valentin (Lee, n.d.).

Ang Lihim ni Antonio (Antonio's Secret, 2008) stars Antonio (Kenji Garcia) who is "a curious fifteenyear-old boy.... beginning to come to terms with his own sexuality" (Caw, 2008). Antonio's exploration of his sexuality and identity picks up steam with the involvement of his uncle (Jonbert played by Josh Ivan Morales) into Antonio and his mother's lives (Caw, 2008).

Joey Paras is a gay breadwinner in the movie Bekikang (2013) (Marasigan, 2013). The movie is about the lead character's old flame (Tom Rodriguez) who leaves his son Potpot to Bekikang (Joey Paras). Bekikang later realized that "real family needn't be bound by blood" (Marasigan, 2013).

Finally, Girl Boy Bakla Tomboy (Girl Boy Gay Lesbian, 2013) stars Vice Ganda playing the characters of Mark, Girlie, Peter and Panying. The siblings have differing sexual orientations and were reunited to save Peter's life (Marasigan, 2014).

\section{Framework and method}

This study is informed by the political economy of the media which analyses the social (and power) relations which affect the production, distribution, and consumption of media products, communication texts, and other resources. Fairclough's Critical Discourse Analysis model (1995) was used as a method to analyze the text according to three levels of process or layers of meaning:

- The micro level which guides the description of the visual, verbal, and audio cues or elements in the movies

- The meso level which relate to the interpretation of the text to arrive at discourses (values, connotations, interests, etc...) in the movies and

- The macro level which aim to explain sociohistorical factors and practices which affect the overall production and distribution of the text such as the regime, context, ideology, power relationships, etc...

Categories of gay issues and themes were arrived at inductively. In looking for gay issues and themes, the researchers coded specific scenes, dialogues, and patterns in the films in search for common symbols or visual elements, use of language, and audio or verbal cues.

The first objective of the paper which is to surface gay issues in select mainstream and indie films shall be answered after the analysis of the micro and meso levels in Fairclough's CDA model. The second objective which is to explicate the nuances between indie and mainstream films will be based on the analysis in the macro level.

\section{RESULTS AND DISCUSSION}

The gay issues presented in the films largely involve or relate to the following:

- Representation: sexual orientation, gender identity and expression of the gay character 
(loud vs. discreet, tastes/ preferences in sex/ sexual partners, etc...)

- Acceptance: both personal and social (coming out, acknowledgement vs. denial; gay character's relationship with his family, peers, friends, and the community)

- Rights and protection: access to rights to marriage, adoption, healthcare, employment, and education; protection from discrimination, hate crimes/ bullying; issues of social stratification, class or status

\section{Representation}

We found out that there are two dominant representations of gays in Philippine cinema-the loud and the macho. The loud or the screaming faggot stereotype is characterized by the use of gay language, perpetually screaming characters who laugh and shriek loudly at the slightest provocation. On the other hand, the second gay stereotype is that of the masculine, straight-acting men equivalent to the Western homosexual (homosexual being a signifier for orientation).

A similar finding is found in the literature about gay representation in Philippine cinema. Payuyo (2012) in her study of select Filipino gay-themed films found that there are two dominant gay characters in Philippine cinema-the parlorista/ palengkerang bakla (screaming faggot/ flaming gay/ cross-dressing) and the Brokeback-mountain type (named after the movie starring two macho, discreet, "straight-acting" gay characters).

In the movies we reviewed, Bekikang (2013) and Girl Boy Bakla Tomboy (Girl Boy Gay Lesbian, 2013) capitalized on the flaming gay stereotype while Ang Pagdadalaga ni Maximo Oliveros (The Blossoming of Maximo Oliveros, 2005) reinforced the sissy gay stock character. Gay characters in Ang Lihim ni Antonio (Antonio's Secret, 2008), on the other hand, are of the straight-acting/ macho/ discreet type. Sa Pusong Mamon (Soft Hearts, 1998) and Sa Paraiso ni Efren (Efren's Paradise, 1999) have gay characters who, while of Brokeback-mountain physical attributes, are undoubtedly effeminate, with their voice, gestures, and movement serving as gender cues. Allan Paule and Eric Quizon are "macho" insofar as their physical appearance is concerned.
However, they can cross-over to the flaming gay stereotype through cross-dressing and their flamboyance.

Using Neil Garcia's notes (2008), the flaming gay is the familiar image of gays in Philippine mainstream cinema and culture (drag queens, the cross-dressing type, etc...). The flaming gay has the straight/ heterosexual male for their object of desire and they compete with females for the heterosexual man's love. Most of the gay characters in these films are also cast in "traditionally feminine" or domestic roles. Eric Quizon in Pusong Mamon (Soft Hearts, 1998) has meticulous and expensive taste for food, groceries, and household amenities.

Maxi in Ang Pagdadalaga ni Maximo ni Oliveros (The Blossoming of Maximo Oliveros, 2005) cooks for his family and takes care of his family's needs like a "mother". Joey Paras in Bekikang (2013) and Vice Ganda in Girl Boy Bakla Tomboy (Girl Boy Gay Lesbian, 2013) have important roles as helpers at home and that their characters are also depicted as self-sacrificing. Allan Paule in Sa Paraiso ni Efren (Efren's Paradise, 1999) is a social worker, a "nurturing" role which is a "feminine" attribute (having "motherly" qualities).

The heterosexual order posits a linear alignment among sex, gender, and sexuality (Butler, 1993). Given the examples in the movies, there is no linear alignment among sex, gender, and sexuality. Eric Quizon in Pusong Mamon (Soft Hearts, 1998) is male yet takes on "feminine" gender roles and, in spite of his "feminine role" in relationships, prefers another masculine homosexual for a partner. Antonio, who is implicitly cast into "feminine roles", develops a desire for his macho uncle. However, it must be noted that in Bekikang (2013) and Girl Boy Bakla Tomboy (Girl Boy Gay Lesbian, 2013), the gay characters have straight, heterosexual men as their objects of desire/ love interests. These suggest that gay characters are more of females trapped in a man's body and that they would feel/ be more like a "natural" woman through a heterosexual man's love. In other words, the flaming gay characters are heterosexual in orientation because as "women", they desire the straight man.

Gay characters who are portrayed as "women" trapped in a man's body and desiring a heterosexual man still reinforce the heterosexual matrix or the 
alignment between gender and sexuality. In other words, the representation of the heterosexual flaming gay characters as heterosexual (because they are "women" desiring heterosexual men/ the opposite sex or males) is still heteronormative-that heterosexuality is the dominant form of desire and that anything which deviates from it is suppressed and disallowed as I shall discuss in succeeding paragraphs.

As such, the common image of gays in general, as reinforced in the films, is one that does not reinforce diversity but one that is bound by expectations of the heterosexual majority - that gays are still "women" trapped in a man's body. However, though they are "women" through their choices, attributes, and desires, the gay characters are not quite considered "real women" because they are an abomination of the female species. Such ordering further creates a minority (gays who are copy-cat females) within the minority (women) and imposes the primacy of males/ men in the hierarchy.

\section{Acceptance}

Homophobia underscores issues of acceptance. According to Neil Garcia, homophobia is the "socially endorsed, prejudiced hatred and persecution of gays and lesbians because of their same-sexual orientation" (2008, p. 6). Homophobia can be institutional and personal. The former is a product of a system privileging heterosexual goals and values of procreation or reproduction. Hence, institutional homophobia can result in lack of access to marriage, healthcare, and benefits accorded to homosexuals. Personal homophobia, on the other hand, stems from lack of exposure to homosexuals that lead to ignorance, prejudice, and possibly, bigotry (Garcia, 2008).

In Pusong Mamon (Soft Hearts, 1998), Albert Martinez' father still thought that he could "un-gay" his son even as the latter already came to terms with his sexuality. In Ang Lihim ni Antonio (Antonio's Secret, 2008), the lead character experienced a strained relationship with his best friend when the latter discovered that Antonio was gay. Allan Paule (characterized as generous and supportive) and Albert Martinez (shown to be "decent" and professional) did not find unconditional acceptance in the heterosexual world.
While the gay characters are shown to possess redeeming values such as their unconditional love for their families, their generous spirit, the same gay characters are still arguably "othered". Baytan (2008) said that the "limited notion of gayness is symptomatic of the dominant hegemonic culture's continuous attempts to fossilize the bakla or gay identity - to subject him to its unchanging master narrative of the suffering abject" (p. 191). In the movies reviewed, the gays did not end up with their objects of desire. The gays are policed and repressed by the heterosexual order as the "tunay na lalaki" (real man/ object of desire) ended up with women whom they later married and had families with.

In Sa Paraiso ni Efren (Efren's Paradise, 1999), in spite of the lead character's generosity and support, his love and desire are unrequited. In Bekikang (2013), Joey Paras did not end up with Tom Rodriguez even as the former adopted the latter's son. One might also wonder if Maxi's family in Ang Pagdadalaga ni Maximo Oliveros (The Blossoming of Maximo Oliveros, 2005) would treat him differently had he behaved irresponsibly or acted against his family's wishes. In the movies mentioned, the acceptance of gays is hinged on their contributions or socio-economic status, and their commitment to helping their families and society in general.

Seen through the lens of critical political economy which examines how access to capital affects social and political relations (Wasko et al., 2014), gay issues in mainstream films still cater to the heterosexual market's demands and expectations of the bakla. In the indie films reviewed, there are missing discourses about the gay identity and experience. Discourses arising from these movies are often limited to notions such as gay as the milking cow, rendering affective labour, and in some cases, promiscuous. What these imply is that the value of acceptance for gays in these films is contingent on having positive qualities or based on affective labour. There are problems with acceptance based on affective labour.

First, what would happen if gays are no longer cast in a favourable light? Would they still be accepted? Second, personal and institutional homophobia would still persist regardless of whether gays are presented positively. Prejudice and bigotry do not magically dissipate even as gays are cast in a favourable light. The seeming precondition for acceptance-for gays to have positive qualities and contributions - is a 
double-standard. After all, no such expectation exists for heterosexuals

\section{Rights and protection}

We found that the gay character's rights and protection intersect with issues of class and status. Rights refer to the homosexual's access to marriage, adoption, healthcare, employment, and education. Protection, on the other hand, refers to the guarantees of the law or state against discrimination, hate crimes/ bullying, etc... Issues of social stratification, class or status intersect with marginalization, acceptance, and political currency of the gay characters and community.

Gay marriage is a theme in Pusong Mamon (Soft Hearts, 1998) with Eric Quizon and Albert Martinez seen as attending weddings of their gay couple friends. Later, Lorna Tolentino joins them in church for the baptism of their gay friends' son. Towards the end of the movie, Albert Martinez is shown to be proposing to Eric Quizon. Marriage is seen as the long-awaited pinnacle of the relationship as it signifies perpetual commitment. Meanwhile, adoption is another issue shown in both Pusong Mamon (Soft Hearts, 1998) and Bekikang (2013). It must be noted, however, that the lead character in Bekikang was only able to adopt Tom Rodriguez' son after becoming wealthy and successful. In Pusong Mamon, adoption and marriage are options only available to well-to-do, upper-class gay couples.

It is not surprising then to see that marriage and adoption are not among the issues presented in Girl Boy Bakla Tomboy (Girl Boy Gay Lesbian, 2013) and Ang Pagdadalaga ni Maximo Oliveros (The Blossoming of Maximo Oliveros, 2005). Themes on poverty/ hardships in life arise in these two filmsMaxi living is in a crime-stricken area and Vice Ganda experiences a life far from the comfort and luxury that his siblings enjoy in the US. For Maxi, bullying/ harassment are the issues, he is a gay character against the backdrop of crime and poverty.

In Ang Lihim ni Antonio (Antonio's Secret, 2008), the lead character is a victim of crime. Antonio was raped by his uncle and he took the fall for the crime committed by his mother. Sexual abuse in a consensual, homosexual relationship is what Antonio experienced in the hands of his uncle. Meanwhile, Antonio's uncle and Efren solicit money in exchange for sex. Crime and poverty are part of Antonio's, his uncle's, Efren's, and Melvin's narratives.

The issues of rights and protection for the gay characters must be filtered through matters of social stratification, class or status as these intersect with marginalization, acceptance, and political currency. To quote Neil Garcia (2008), "gay theory should include a local and materialist critique of the class system as issues of homosexual prostitution, discrimination, and oppression in general are intimately linked to class-supremacist ideologies" ( $p$. 14).

The consequences of personal and institutional homophobia compelled movies in this paper (intentionally or not) to rearticulate the right for gays to marry (Pusong Mamon/ Soft Hearts, 1998), adopt (Bekikang, 2013), be protected from crimes (Ang Pagdadalaga ni Maximo Oliveros/ The Blossoming of Maximo Oliveros, 2005; Sa Paraiso ni Efren/ Efren's Paradise, 1999), and Ang Lihim ni Antonio/ Antonio's Secret, 2008) and have access to a good life (Girl Boy Bakla Tomboy/ Girl Boy Gay Lesbian, 2013). Institutional or personal homophobia succeeds in creating a minority and stigmatizing the gays. Needless to say, such "minoritizing" and "stigmatizing" (Garcia, 2008) have had an impact on the gay's access to rights, towards furthering the structural limitations and institutional hurdles to their access and call for protection.

Indie vs. Mainstream: Production, Technology, and Themes

The succeeding discussion addresses the second objective - to explicate the nuances of indie and mainstream films. The major differences of indie films to its chief counterpart, mainstream motion pictures, include its economic mode of production (budget and its implication on aesthetics, casting, etc...), technologies used (camera, editing, storage device), and techniques of production and themes (formula, genre, narrative structure).

The first difference of indie films to that of mainstream films is related to budget. A review of Jose Gutierrez III (2012) on Baumgartel's book on Southeast Asian independent cinema (2012) classified indie films as those which were not produced by major film outfits or were produced "independent" of the major film studio system such Star Cinema, Regal Films, Viva Films or GMA Films 
in the case of the Philippines. The major production companies create big-budget films which are shown in cinemas nation-wide.

Financial constraints are evident in indie films based on their shoot locations, visual effects, and aesthetic components like make-up, wardrobe, and props (Bleasdale, 2008). Locations in Ang Lihim ni Antonio (Antonio's Secret, 2008) and Ang Pagdadalaga ni Maximo Oliveros (The Blossoming of Maximo Oliveros, 2005) were shanties in Manila. In the mainstream film Pusong Mamon (Soft Hearts, 1998), the gay couple lives in an upper-class subdivision. Of course, all these differences still depend on the central plot and the narrative of the characters.

Mainstream films hire popular artists as their talents like Vice Ganda, Eric Quizon and Albert Martinez. These actors are highly recognized in Philippine television and cinema. Moreover, most of these actors are openly gay (Vice Ganda, Joey Paras) and often seen in Philippine television as cross dressers and loud gay characters. On the other hand, Kenji Garcia (Antonio) and Nathan Lopez (Maximo) are actors whose names rarely appear on TV and film. The use of popular stars together with their gender roles create the screaming faggot stereotype in mainstream films, compared to the portrayal of gay characters in indie films who are more discreet, straight-acting closeted homosexuals.

It is of no surprise then that with the profit-orientation of mainstream films, the aesthetic elements and sophisticated production tools and equipment are used to sell the movie to as wide an audience base as possible. Needless to say, peddling and pandering to the demands and expectations of the mass market in order to sell and profit have had negative consequences to representation and portrayal of gays in Philippine cinema.

Mainstream films are ridden with loud gay characters or the screaming/ flaming gay stereotype. Gays are treated as the suffering abject, the laughing stock of the mass market. This pervasive portrayal and representation is argued to have stifled the goals of acceptance and integration for members of the gay community. The visibility of gays in Philippine cinema is indeed a double-edged sword - they are either liberated from the previous labels or boxed further in new categories.
Meanwhile, as opposed to mainstream films which rely on product placements, advertising and sponsorships for profit, indie films rely on critical recognition (often in local and international film festivals) for viewership and circulation of films. With their limited aesthetic elements, the less sophisticated technology in indie films can be perceived as its strength more than its weakness. As technology developed, indie filmmakers adopted to the portability, flexibility, and devaluing price of digital cameras. The technologies used in creating independent films also include affordable materials like digital video cameras and cheap computer editing and enhancing tools (Bleasdale, 2008; Gutierrez, 2012; Science and Technology Council, 2012).

The portability and flexibility of technology, along with the "independence" of indie films from mass market demands and expectations, have allowed indie filmmakers to shoot whenever, wherever, and whatever-opening the possibility for expanding, exploring, and diversifying gay experiences and narratives which have never been caught on camera before. While some elements clearly work to the advantage of indie films, there is a question on the extent to which indie films were able to subvert prevailing gay stereotypes in mainstream films. If anything, the experimentation for which indie films is known for is yet to provide an alternative perspective and discourse to gay identity and experience.

In relation to techniques and narratives, mainstream films use continuity editing, predictable story lines, a formula for characters, and establishing shots which usually familiarize the viewers with the setting (King, 2005; as cited in Szabo, 2010). On the other hand, indie films use off-centre or inexact framing, the practice of taking shots with unusual angles and restricted views, and the habit of interchanging close shots and long shots as the story develops (King, 2005; as cited in Szabo, 2010). Indie films also have open-ended conclusions, rely heavily on dialogues to establish characters, and often have anti-Hollywood or non-formulaic story lines.

In a study by Fuentes, et al. (2015), indie films usually tackle and show stories outside the common narratives and techniques of mainstream films. With limited amount of budget, indie films represent what is close to reality using available funds for its operation as they go against the standard formula of mainstream films. Does "indie" then mean or connote 
"progressive"? While mainstream films are still remiss in their presentation of gay issues. Indie films, for their part, have left much opportunity to explore the topic of gay identity and experience with much depth.

In sum, Herman and Chomsky (2002) argued that there are structural factors and institutional forces which determine the content (and the limitation of content) in media texts. Films are no stranger to ownership, control, financing, elite's interests, and business considerations in the political economy of mass media. The way these films present, represent, explore, and discuss gay issues has a lot to do with who decides what to show in these films, what constitutes "acceptable" messages, and which market is catered to. In other words, assessing how "progressive" films are in presenting gay issues is secondary to understanding the structural factors and institutional forces which sustain the films.

\section{CONCLUSION}

The presentation of gay issues and themes in mainstream films is still very much bound to conform to the expectation of the heterosexual majority. The acceptance of gays is based on their positive qualities and contributions. In spite of their self-sacrifice and positive qualities, gay characters are still disrespected and are often unrequited in love and desire. Most of the mainstream movies expectedly fall short in presenting gay issues with depth and breadth. The appeal to the mass market and the use of tried and tested formula disallow or make it difficult for mainstream films to explore gay issues and themes more substantially and meaningfully.

In a similar vein, the expectation for indie films to provide an alternative or different perspective to mainstream films' treatment of gay issues is yet to be fulfilled. In spite of the many attempts to diversify gay representation, gay stereotypes are still pervasive. There are departures from the portrayal of gays as the screaming faggot. However, these departures in portrayal also support existing and breed new stereotypes (gays as promiscuous/ milking cow, the paying customers, and pretentious/ two-faced/ manipulative, despicable for being pretentiousness about their sexuality).

Finally, it is worth noting that there is no singular, objective definition and standard for what constitutes a progressive presentation of gay issues. In this regard, the reach and wide audience base of mainstream films and potential of indie films for experimentation can be harnessed. What exactly constitutes a progressive representation of gay issues and themes? This is a question that only authors and filmmakers can answer.

The mode of production and the use of technology can only do so much in the way gay issues are presented in films. In the end, it is still the author's intention, approach, and execution which can affect the audience's perceptions of and the public discussion about gay issues and themes. It is expected that authors will submit carefully written and proofread material. Careful checking for spelling and grammatical errors should be performed. Papers should clearly describe the background of the subject, the authors' contribution, including the methods used, results and concluding discussion on the importance of the work from both scholarly and managerial perspectives.

\section{REFERENCES}

Baytan, R 2008 'Bading na bading: evolving identities in Philippine cinema', in F Martin, P Jackson, M McLelland, and A Yue (eds.), Rethinking genders and sexualities, University of Illinois Press, Urbana and Chicago.

Bleasdale, J 2008, 'Review: D. K. Holm (2008) independent cinema', Film-Philosophy, vol. 12, no. 2, pp. 52-156.

Butler, J 1993, 'Imitation and gender insubordination', in H Abelove, M A Barale, and D Halperin (eds.), The lesbian and gay studies reader, Routledge, London.

Caw, D 2008, 'Ang Lihim ni Antonio', Philippine Entertainment Portal, 11 February, viewed 10 March 2016, http://www.pep.ph/guide/indie/1585/Ang-Lihim-niAntonio-showcases-the-anatomy-of-desire-andlonging\#r7VeECospzVDBS0V.99

Crow, J n.d., 'Pusong mamon', The New York Times, n.d., viewed 12 March 2016, http://www.nytimes.com/movies/movie/186616/Pusongmamon/overview

Deming, M n.d., 'Sa paraiso ni Efren', The New York Times, n.d., viewed 12 March 2016, http://www.nytimes.com/movies/movie/201804/Sa-paraisoni-Efren/overview

Fairclough, N 1995, Media discourse, Edward Arnold, London.

Fuentes, G, Labilles, D, \& Reyes, R 2015, 'The perception of indie films of selected Intramorous based audiences' International Journal of Social Science and Humanity, vol. 5, no. 1 , pp. 145-148. 
Garcia, N 2008, Philippine gay culture: Binabae to bakla, silahis to MSM, The University of the Philippines Press, Quezon City.

Ghaziani, A 2011, 'Post-gay collective identity construction', Social Problems, vol. 58, no. 1, pp. 99-123.

Ghaziani, A 2015, 'The queer metropolis.' in J DeLamater and R Plante (eds.), Handbook of the Sociology of Sexualities, Springer International Publishing, Switzerland.

Gutierrrez, J 2012, 'Filipino indie by way of Southeast Asian independent cinema', Plaridel, vol. 9, no.2, pp. 97104.

Herman, E \& Chomsky, N 2002, Manufacturing consent: The political economy of the mass media, Pantheon Books, New York

Jamon, R 2006, 'In full bloom. A movie review of Ang Pagdadalaga ni Maximo Oliveros', Plaridel, vol. 3, no. 2, pp. 151-166.

Kehoe, K \& Mateer, J 2014, 'Enhancing the competitiveness of an independent feature film production company through the application of new digital technologies using knowledge transfer: A case study of Green Screen production', Inimpact: The Journal of Innovation Impact, vol. 7, no. 1, pp. 244-256.

Lee, N, n.d., 'The blossoming of Maximo Oliveros', The New York Times, n.d., viewed March 102016, http://www.nytimes.com/movies/movie/340452/TheBlossoming-of-Maximo-Oliveros/overview

Marasigan, Z2013,'“Bekikang': The brand new face of comedy', Rappler, 25 October, viewed 10 March 2016, http://www.rappler.com/entertainment/movies/42

$170-$ bekikang-review-brand-new-face-of-comedy

Marasigan, Z 2014, “Girl, Boy, Bakla, Tomboy': A hilariously absurd party of four', Rappler, 5 January, viewed 12 March 2016, http://www.rappler.com/entertainment/movies/47249mmff-girl-boy-bakla-tomboy-review

Payuyo, L 2012, 'The portrayal of gays in popular Filipino films, 2000 to 2010', in F Candaliza-Gutirrez and A Soco (eds.), Philippine Sociological Review, vol. 60 pp. 293-322.

Science \& Technology Council 2012, The Digital Dilemma 2: Perspectives from Independent Filmmakers, Documentarians and Nonprofit Audiovisual Archives, Academy of Motion Picture Arts and Sciences, US.

Szabo, C 2010, 'Independent, mainstream and in between: How and why indie films have become their own genre', PhD Thesis, Honors College, viewed 20 March 2016, http://digitalcommons.pace.edu/honorscollege_theses/96

Wasko, J, Murdock, G, \& Sousa, H (Eds.) 2014, The handbook of political economy, John Wiley \& Sons, Ltd, West Sussex. 